\title{
A LIBERDADE DA CONSCIÊNCIA HUMANA: O QUE LUTERO E KIERKEGAARD TEM A NOS DIZER?
}

\author{
Heloisa Allgayer ${ }^{1}$ \\ Universidade de Caxias do Sul (UCS) \\ https://orcid.org/0000-0002-2597-6750 \\ E-mail: heloisaallgayer@gmail.com
}

\section{RESUMO:}

Nesse artigo procuro trazer a luz as convergências e divergências entre o reformador alemão Marinho Lutero e o filósofo Dinamarquês Kierkegaard. Para tanto o texto foi subdividido em quatro capítulos para que pudesse ser possível trazer a s ideias principais dos autores. O diálogo entre Lutero e Kierkegaard, onde o autor defende a liberdade de consciência como sendo uma liberdade de, do modo como Lutero o faz, uma vez que a nossa liberdade só é encontrada quando amamos a Cristo, com uma paixão tão distinta que estamos dispostos a arriscar tudo por ele e concomitantemente sacrificar tudo por ele. Segundo Kierkegaard (1978) o sujeito que é capaz de ficar sozinho no mundo, consultando apenas a sua consciência é um herói. Kierkegaard apela para Lutero, o monge solitário que enfrentou o Imperador e o Papa, levando primeiramente à criação e ao fortalecimento da consciência no silêncio e na solidão. Sendo assim, somente o sujeito solitário diante de Deus, disposto a fazer todos os sacrifícios por Deus pode ser livre, enquanto o segundo Lutero, levou a uma visão que leva os sujeitos à abolição da consciência, buscando o perdão dos pecados em Cristo para que seja possível se divertir em vida. $O$ amor de Deus, que para Lutero nos leva a liberdade para Kierkegaard nos mantém aprisionados e angustiados, pois, o sujeito terá a consciência de que jamais conseguirá retribuir tal amor. Para que seja possível aplacar tal angústia deve ter uma vida totalmente entregue à Ele.

PALAVRAS-CHAVE: Lutero; Kierkegaard; Angústia.

\section{THE FREEDOM OF HUMAN CONSCIOUSNESS: WHAT DO LUTHER AND KIERKEGAARD HAVE TO TELL US?}

\begin{abstract}
:
In this article I try to bring to light the convergences and divergences between the German reformer Marthin Luther and the Danish philosopher Kierkegaard. For this purpose, the text was subdivided into four chapters so that it could be possible to bring the main ideas of the authors. The dialogue between Luther and Kierkegaard, where the author defends freedom of conscience as being a freedom from, as Luther does, since our freedom is only found when we love Christ, with a passion so distinct that we are willing to risk everything for him and at the same time sacrifice everything for him. According to Kierkegaard (1978) the subject who is able to be alone in the world, consulting only his conscience is a hero. Kierkegaard appeals to Luther, the solitary monk who faced the Emperor and the Pope, leading first to the creation and strengthening of consciousness in silence and solitude. Thus, only the lonely subject before God, willing to make all sacrifices for God can be free, while the second Luther led to a vision that leads subjects to the abolition of conscience, seeking the forgiveness of sins in Christ so that it is possible to have fun in life. The love of God, which for Luther leads us to freed om for Kierkegaard, keeps us imprisoned and anguished, because the subject will be aware that he will never be able to reciprocate such love. In order to be able to appease such anxiety, you must have a life totally surrendered to Him.
\end{abstract}

KEYWORDS: Luther; Kierkegaard; Anxiety.

\footnotetext{
${ }^{1}$ Doutor(a) em Biologia pela Universidade do Vale do Rio dos Sinos (UNISINOS), São Leopoldo - RS, Brasil. Pós-doutorando(a) na Universidade de Caxias do Sul (UCS), Caxias do Sul - RS, Brasil.
}

ALLGAYER, Heloisa. A liberdade da consciência humana: o que Lutero e Kierkegaard têm a nos dizer?. Griot : Revista de Filosofia, Amargosa - BA, v.21 n.3, p.298-318, outubro, 2021. 


\section{Introdução}

Nesse trabalho será abordada a noção de liberdade da angústia para Lutero e Kierkegaard, culminando no diálogo entre os dois autores. Para tanto ele foi dividido em três capítulos.

No primeiro capítulo foi realizada uma análise da obra Da liberdade do Cristão (1520) de Martinho Lutero utilizando-se a versão bilíngue da obra. Na primeira parte houve uma contextualização histórica do autor e em seguida foi realizada a análise propriamente dita. Foram trazidos os principais pontos da obra que culminam na conclusão de que, a liberdade concebida por Lutero ocorre pela graça divina por meio da fé, e, a consequência disso é a salvação do indivíduo, que se torna livre de toda maldade, da preocupação espiritual e da vida terrena.

No segundo capítulo foi realizado uma análise da noção de angústia para o filósofo dinamarquês Søren Kierkegaard, para tanto, foi realizada uma análise da obra $O$ conceito de angústia que foi escrita sob o pseudônimo de Vigilius Haufniensis no ano de 1844. De forma resumida $\mathrm{O}$ conceito de angústia, Kierkgaard se refere a angústia como uma forma de adquirir a salvação. É a angústia que possibilitará que o sujeito arbitre, se autoconheça e se preocupe com a responsabilidade social, conduzindo-os a uma condição de um imediatismo não consciente até uma análise autoconsciente. $O$ sujeito vem a ser consciente do seu potencial por meio da experimentação da angústia/ansiedade. Portanto, a ansiedade pode ser vista como a conjuntura para o pecado, porém, também pode ser o rumo para a realização ou averiguação da identidade e liberdade de cada sujeito.

No terceiro capítulo foi realizada a análise da crítica de Kierkegaard para a noção de liberdade de Lutero. Para tanto, foi utilizado diversos materiais, que levam a Kierkegaard a concluir de que o amor de Deus não liberta o Cristão da angústia.

Segundo Kierkegaard (1978) o sujeito que é capaz de ficar sozinho no mundo, consultando apenas a sua consciência é um herói. E para argumentar em relação a isso Kierkegaard apela para Lutero, o monge solitário que enfrentou o Imperador e o Papa, levando à criação e ao fortalecimento da consciência no silêncio e na solidão, solitário diante de Deus, disposto a fazer todos os sacrifícios por Deus e esse é o sujeito livre. Enquanto o Lutero pós Worms leva a uma visão que acabará por levar à abolição da consciência, buscando o perdão dos pecados em Cristo para que seja possível se divertir em vida.

\section{Martinho Lutero e a liberdade do cristão}

Nesse capítulo será realizada uma análise da obra Da Liberdade do Cristão (Von der Freiheit eines Christenmenschen), 1520. Tal obra, é o terceiro tratado do reformador alemão, sendo antecedido pela An den christlichen Adel deutscher Nation (À nobreza cristão da nação alemã) (agosto de 1520) e pelo prelúdio de captivitate Babylonica ecclesiae (Von der babylonischen Gefangenschaft der Kirche, Do cativeiro babilônico da Igreja) (outubro de 1520).

Resumidamente, o tratado traz a luz a noção de que como os cristãos são filhos de Deus totalmente perdoados, visto isso, eles não são mais obrigados a seguir a lei de Deus para lograr a salvação, contudo, de boa vontade eles servem a Deus e ao próximo. "Um cristão é um senhor livre de todas as coisas e não submisso a ninguém. Um cristão é um servo obsequioso e submisso a todos." (LUTERO, 1997, p. 25)

\subsection{Da liberdade do cristão (Von der Freiheit eines Christenmenschen)}

A obra Da liberdade do Cristão do reformador alemão foi redigida com o intuito preliminar de expor para o Papa Leão X a doutrina bíblica cristã da justificação pela fé. Nesse trabalho,

ALLGAYER, Heloisa. A liberdade da consciência humana: o que Lutero e Kierkegaard têm a nos dizer?. Griot : Revista de Filosofia, Amargosa - BA, v.21 n.3, p.298-318, outubro, 2021 
Lutero expõe a inteira liberdade do cristão, sendo ele, o sacerdote e rei sobre todas as coisas exteriores, porém, como condição ter um perfeito amor ao próximo. Todavia, o Papa Leão X, como referido anteriormente não aceitou a obra e a considerou ímpia. Lutero, apesar das objeções da cúria, publicou Da liberdade do Cristão em alemão, alvitrando para toda a sociedade. Na obra, como será visto, o que norteia é a ideia de liberdade associada a ideia de servidão.

\subsubsection{Da liberdade do cristão: liberdade e servidão}

Lutero, em sua obra, argumenta em favor da liberdade do cristão, porém, tal liberdade esta norteada pela ideia de servidão. Já no início do tratado, o autor afirma que "um cristão é um senhor livre sobre todas as coisas e não se submete a ninguém" (LUTERO, 1998, p.25), contudo da mesma forma, "um cristão é um súdito e servidor de todas as coisas e se submete a todos" (LUTERO, 1998, p.25). Essas asserções que a priori são aparentemente contraditórias ocorrem segundo Lutero, pois, todo aquele que crê em Cristo tem uma natureza dual que é espiritual e corporal. Através da alma o ser humano é nomeado de homem espiritual, interior e novo; através da carne é nomeado como homem corporal, velho e exterior. Visto isso, a relação entre liberdade e servidão se mantém porque mesmo o homem sendo livre, justificado pela fé, ele continua, todavia, vivendo em sua vida física na Terra. Nessa vida, o sujeito possui um corpo que precisa reger e coexistir com outras pessoas, e as obras são a forma para a sua satisfação, principalmente, visto que somente é possível amar e servir a Deus quando se serve se ama o próximo, pois, "da fé fluem o amor e o prazer em Deus, e do amor flui uma vida livre, animada e feliz, para servir desinteressadamente ao próximo" (LUTERO, 1998, p.49).

Lutero, além disso, adicionou a liberdade e a responsabilidade de reprimir o corpo exterior que é naturalmente mau, visto que, esse fenômeno se contrapõe a alma que é justificada por Deus. Nesse viés o autor tutela que as obras são formas de mortificar o corpo, visto isso, condena o ócio. Sendo assim, o trabalho ganha um papel central, sendo de suma importância para a dignificação do homem, honrando a Deus, ocupando o corpo e o tempo ocioso, resguardando-se do mal. Desse modo, justifica:

E por isso que o homem, por causa do seu próprio corpo, não pode sucumbir à ociosidade, tendo de praticar muitas boas obras a fim de subjugá-lo e não deixar que as obras sejam o verdadeiro bem capaz de torná-lo devoto e justo. (LUTERO, 1998, p.51)

Desse modo, cada qual pode encontrar a medida e o para mortificar o corpo, jejuando, vigiando e trabalhando o quanto considera necessário para reprimir os impulsos de seu corpo. (LUTERO, 1998, p.51)

Nesse sentido, o reformista, se mantém ligado a tradição cultural cristã, já que para a mesma o trabalho é um modo de se livrar das armadilhas do diabo. Dantes, São Bento afirmou que "não fazer nada é ruim para a alma, por isso, em certas horas, os irmãos devem se ocupar no trabalho manual e noutras horas na leitura divina". (SÃO BENTO, 1993, p.83). Visto isso, há um alinhamento no que concerne o trabalho como forma de escapar do ócio. Logo, o trabalho é visto como um meio divino, concedido aos cristãos, como forma de servidão ao próximo e a Deus, reprimindo o corpo físico, ou seja, os impulsos maléficos, dominando-o em serviço à Deus.

O trabalho, para o reformador, se dá tanto no âmbito intelectual quanto no âmbito manual. Desse modo, seu entendimento sobre o trabalho, o ligava mais aos medievais do que aos modernos. Para Lutero, o trabalho foi idealizado como um instrumento divino que tem como função dominar o corpo à serviço de Deus, e as obras têm validade somente se são mediadas pela fé, ocorrendo em decorrência dela, de modo que, o homem bom e justo pratica obras justas e boas (Lutero, 1998). À vista disso, segundo o reformador, servir ao próximo de modo altruísta e as boas 
obras são obrigações do cristão na vida terrena. E nesse aspecto Lutero segue Santo Agostinho, cuja cidade dos homens serve a cidade de Deus (Saint Augustine, 1948), visto que, a própria fé que liberta é a fé que cria responsabilidades, desse modo, o cristão torna-se servo de todos. A justificação por fé e graça conotada por Lutero, segundo Wachholz (2008), simboliza uma imensa libertação do eu uma vez que a excessiva inquietação pela salvação leva a uma cultura excessivamente individualista, cujo lugar é cedido para um cuidado em favor do bem comum, da ecologia e da justiça social.

Esse legado deixado por Lutero é de suma importância, visto que, a liberdade e a responsabilidade são associadas, porque mesmo justificado, o sujeito é responsável pela sua vida que deve ser por ele direcionada e tratada na esfera da razão humana. Como consequência da fé, o cristão tem o dever de praticar as boas obras e cuidar do próximo, não meramente como atos de filantropia cristã como determinavam os medievais e sim como ações da solidariedade do ser humano mediado pela razão. Sendo assim, segundo Lutero:

Ora, portanto da fé fluem o amore o prazer em Deus, e do amor flui uma vida livre, animada e feliz, para servir desinteressadamente ao próximo. Porque, assim como o nosso próximo padece necessidades e carece do que nos sobra, nós também padecíamos necessidades diante de Deus e carecíamos de Sua Graça. Por isso, tal como Deus nos ajudou desinteressadamente por meio de Cristo, nós também devemos realmente ajudar ao próximo por meio do corpo e de suas obras. (LUTERO, p.63, 1998)

Como pode ser observado na citação referida acima, é devido a fé consciente e do que ela carece que faz com que os cristãos pensem e auxiliem os seus semelhantes. E, devido a distinção entre homem exterior e interior, o reformador argumenta em favor da ideia de que o ser humano nasce escravo do pecado, e por isso, é naturalmente mau, sendo desse modo incapaz de realizar atos altruístas. Visto isso, a fim de que seja possível mudar essa realidade, o ser humano necessita aproximar-se de Deus, e admitir como verdadeira as suas fraquezas, sua natureza má, e consequentemente a não ser capaz para o cumprimento dos mandamentos e agir de forma a praticar o bem. Somente quando ser humano for capaz de reconhecer sua natureza pecaminosa diante de Deus, por meio da graça, passa a crer e a desse modo alcança a fé e a salvação em Cristo, e como consequência, a liberdade verdadeira. Sendo assim, LUTERO $(1998$, p.35) afirma que "Essa é a liberdade cristã: é unicamente a fé, é ela que faz, não que nos tornemos ociosos ou maus, mas que não necessitemos de obra alguma para obtermos a devoção e a bem-aventurança."

\subsubsection{A libertação pela fé}

Através da argumentação exposta no subcapítulo anterior, é possível perceber que, a fé em Lutero é subjetiva, e inicia na experiência subjetiva do próprio Deus e do sujeito que a recebe. Visto isso, o refúgio na Palavra Deus que está imerso nas Sagradas Escrituras, compete para a liberdade do cristão, pois, indicam as promessas divinas e os preceitos cristãos. Os preceitos têm como objetivo exibir a incapacidade humana em frente ao pecado. Um exemplo quanto a isso pode ser dado no décimo mandamento que diz "não cobiçaras" e o ser humano percebe que é impossível não cobiçar, sendo assim, busca em outro lugar o auxílio que é incapaz de encontrar em si. A busca por respostas da sua angústia leva o indivíduo a se sentir ansioso, e somente em Cristo encontra a cesse da sua angústia, pois Ele é Aquele no qual há promessas de justiça, graça, liberdade e paz. Através dessa linha argumentativa, Lutero justifica a ideia de que os preceitos se dirigem a promessas. Eles mostram que o ser humano é incapaz de ser justo, e sua única saída é a graça libertadora que é encontrada em Cristo. 
Tendo aprendido e reconhecido pelos mandamentos a sua incapacidade, o homem, com medo, irá se perguntar como satisfazer ao mandamento, uma vez que é preciso cumpri-lo, pois senão será condenado; assim, acabará se sentindo humilhado e aniquilado aos seus próprios olhos, e não encontrará em si anda que possa torna-lo devoto. Nesse momento, então, vem a outra palavra, a aceitação e a promessa divina, e diz:

\begin{abstract}
Se desejas cumprir todos os mandamentos e livrar-se da cobiça e do pecado, tal como obrigam e exigem os mandamentos, então crê em Cristo, pois nele te prometo toda a graça, justiça, paz e liberdade. Se crês, já as tem, mas se não crês, então, nada tens. Pois o que te é impossível com as obras dos mandamentos, que são muitas e portanto nada valem, te será fácil através da fé. Já que sintetizei na fé todas as coisas, de modo que quem a tem, tudo tem e será bem-aventurado; quem não a tem, nada terá.(LUTERO, p.33,1998)
\end{abstract}

Quando o ser humano possui "o senhor correto" que é Jesus Cristo, ele recebe a graça divina, e nesse momento torna-se livre, e sua alma se une a Deus, tornando-os um só corpo. Quando o sujeito crê em Deus, e o ama, ele está cumprindo o primeiro e grande mandamento, "Mestre, qual é o grande mandamento na Lei? Respondeu-lhe Jesus: Amarás o Senhor, teu Deus, de todo o teu coração, de toda a tua alma e de todo o teu entendimento" (Mt 22, 36-37). No momento, que o sujeito crê em Deus e $\mathrm{O}$ ama, ele está cumprindo o primeiro mandamento, e devido a isso perde a obrigação em relação a todos os outros, todas as leis, vindo a ser bemaventurado e justo.

O desenvolvimento da noção de graça redentora divina desenvolvido por Lutero, segundo Skinner (1996), possibilitou que ele resolvesse o dilema formulado pelo antigo testamento, cuja lei, não permitia que ninguém tivesse esperança de o seguir, e por conseguinte pairava de forma constante o pavor da condenação eterna. Essa é a noção de Cristo que se faz na teologia luterana. É por meio de Jesus Cristo que o ser humano recebe o conhecimento da graça salvadora de Deus e se libertam das obrigações inacessíveis da lei.

A liberdade defendida por Lutero, intenta uma liberdade de consciência, que intenciona orientar os sujeitos nas suas ações diárias, a fim de que a evolução da sua fé e consequentemente de sua consciência, levassem o sujeito a tomar decisões compatíveis com essa fé, ou seja, com a vontade Divina. Nessa perspectiva, o reformador defende que cada indivíduo tem como dever agir conforme a sua própria consciência, sendo prudente nesse mundo por suas próprias ações diante de Deus.

\title{
2.1.3. A libertação pela fé e o sacerdócio universal
}

Nos subcapítulos anteriores foi possível vislumbrar que cada cristão é livre para chegar diante de Deus. Visto isso, todo aquele que crê torna-se um fiel sacerdote de Deus, ou seja, nisso está imbrincado a ideia de sacerdócio universal. Tal ideia desconsidera o sacramento da Ordem, admitido até então pela cúria, dando valor aos indivíduos e o elevando-os a condição de sujeito. Todavia, esse fenômeno é vislumbrado devido a noção de que o homem é justificado pela fé e não pelos méritos e obras que poderiam ser adquiridos por meio de indulgências. Para Lutero, nosso valor é concedido por Deus e independem de todos os elementos externos como nossas realizações e obras. 
devoção e liberdade. Pois todos os itens obras e maneiras supracitados também podem ser adotados e praticados pelo homem mau, hipócrita e fingido. Aliás, de tais criaturas não resulta outro tipo de pessoa, a não ser vaidosos hipócritas. Por outro lado, em nada prejudica à alma se o corpo usar vestimentas profanas e morar, comer, beber e peregrinar em lugares profanos, não rezar, nem executar as obras que os hipócritas supracitados fazem (LUTERO, p. 27, 1998)

A partir do momento em que Lutero trouxe a noção de que exclusivamente pela fé há salvação, há uma elevação do indivíduo forjando-o como cristão e por isso tornando-se digno de aparecer diante de Deus e suplicar pelo próximo. Nesse sentido, não era necessário clérigos para intervir a fim de que fosse possível chegar em Deus nem tampouco eram necessários para a salvação de outrem. Tal fenômeno abalou a hierarquia católica, pois a igreja era uma das principais instituições da época que influenciava de forma direta e vigorosa todos os domínios da sociedade, regularizando todas as ações dos sujeitos.

Além disso, somos sacerdotes; isto é muito mais que ser rei porque o sacerdócio nos torna dignos de aparecer diante de Deus e rogar pelos outros. Porque a ninguém compete ficar diante dos olhos de Deus e rogar, a não ser aos sacerdotes. Portanto, Cristo nos concedeu a capacidade de interceder e rogar espiritualmente pelos outros, do mesmo modo que um sacerdote intercede e roga por seu povo. Contudo, quem não crê em Cristo, nada lhe serve para o bem; ele se torna um servo de todas as coisas e tudo o aborrecerá. (LUTERO, 1998, p.43)

\subsubsection{Da liberdade}

Lutero argumenta que a liberdade suprema em favor das obras e do serviço ao próximo. As obras para o reformador não passam de um voluntariado unicamente para agradar a Deus, atendendo e beneficiando o próximo.

Essas seriam obras meramente voluntárias feitas apenas para agradar a Deus e não alcançar uma devoção que Ele já possuía e com a qual todos nós naturalmente teríamos nascido. Portanto, isso vale também para as obrar de um homem crente que por sua fé é colocado no paraíso e criado de novo; ele não necessita de nenhuma outra obra para tornar-se devoto. Contudo, a fim de que não sucumbisse à ociosidade e trabalhasse e guardasse o seu corpo, foram-lhe ordenadas tais obras voluntárias apenas para agradar a Deus. (LUTERO, 1998, p.53)

Por conseguinte, estas duas sentenças são verdadeiras "As obras boas e devotas jamais tornam o homem bom e devoto, mas o homem bom e devoto realiza obras boas e devotas" e "As obras más jamais tornam o homem mau, mas os homens maus realizam obras más". Ou seja, a pessoa deve ser boa e devota antes de realizar todas as boas obras, e estas resultam e emanam da pessoa devota e boa (LUTERO, 1998, p.53)

Desse modo, a liberdade concebida por Lutero ocorre pela graça divina por meio da fé, e, a consequência disso é a salvação do indivíduo, que torna-se livre de toda maldade, da preocupação espiritual e da vida terrena. Por saber que apesar de salvo o ser humano continua vivendo na terra, necessitando reger seu corpo e relacionar-se com o próximo e auxiliá-lo, a noção de liberdade desenvolvida por Lutero é ligada a responsabilidade social.

O reformador intercedeu a favor da liberdade de consciência, invocando que o ser humano não seja somente um indivíduo, mas sim, um sujeito das suas ações que se ocupa fortemente com o coletivo. Tal princípio do dever coletivo extrapola a fé cristã e engloba o pensamento em geral. Desse modo, Lutero colabora para a origem de um cristianismo moderno, dando uma resposta as angústias de seus contemporâneos, assim como da sociedade porvindoura, consequentemente 
sendo um argumento moderno para o momento em que o estruturou, influenciando fortemente tanto o mundo secular quanto o mundo religioso. Visto isso, mesmo com as limitações de sua argumentação e das limitações sociais e culturais em seu período, Lutero contribuiu fortemente e provocou profundas mudanças socioculturais. A doutrina cunhada pelo reformista alemão da justificação pela fé e a defesa da liberdade, retribuem as angústias e as necessidades de sua época, ofertando princípios para refletir em torno da nova sociedade que rompia.

\section{Søren Kierkegaard e o conceito de angústia}

Sucintamente, em $\mathrm{O}$ conceito de angústia, Kierkgaard se refere a angústia como uma forma de adquirir a salvação. É a angústia que possibilitará que o sujeito arbitre, se autoconheça e se preocupe com a responsabilidade social, conduzindo-os a uma condição de um imediatismo não consciente até uma análise autoconsciente. $O$ sujeito vem a ser consciente do seu potencial por meio da experimentação da angústia/ansiedade. Portanto, a ansiedade pode ser vista como a conjuntura para o pecado, porém, também pode ser o rumo para a realização ou averiguação da identidade e liberdade de cada sujeito.

\subsection{Desvelando o conceito de angústia}

Caracteristicamente, todas as obras de Kierkegaard possuem uma oração, dedicatória ou um prefácio. E o Conceito de angústia (KIERKEGAARD, 2015) adicionalmente possui uma longa introdução. Tal obra, traz a ideia de mediação Hegeliana. Para Hegel a mediação é:

$[\ldots]$ não é outra coisa senão a igualdade-consigo-mesmo semovente, ou a reflexão sobre si
mesmo, o momento do Eu para-si-essente, a negatividade pura ou reduzida à sua pura
abstração, o simples vir-a-ser. O Eu, ou o vir-a-ser em geral - esse mediatizar -, justamente
por causa de sua simplicidade, é a imediatez que vem-a-ser, e o imediato. (HEGEL, 1807)

Ou seja, a mediação caracteristicamente é a passagem de uma situação para outra: "um tornar-se Outro; é uma mediação; mesmo que seja apenas passagem a outra proposição," (HEGEL, 1807). A mediação é a linha que conduz a obra do autor dinamarquês. Na obra "O conceito de angústia" Kierkegaard questões como pecado e culpa.

O filósofo traz uma linha argumentativa onde angústia (ansiedade) é um medo sem um foco. Para tanto, o autor traz a luz o exemplo do homem parado a beira de uma construção alta ou penhasco. No momento em que o sujeito olha para baixo, ele sente tanto medo de cair quanto o terrível ímpeto de se jogar. Essa experiência é a ansiedade ou o pavor devido a absoluta liberdade de escolha que nos é apresentada, entre se jogar ou ficar parado. $O$ inteligível fato de o indivíduo possuir total liberdade de fazer algo ainda que seja uma possibilidade amedrontadora, traz à tona sentimentos imensuráveis de pavor. Esse fenômeno foi nomeado por Kierkegaard como vertigem da liberdade.

O filósofo traz a luz como a primeira ansiedade experienciada pelo homem, como sendo, a escolha feita por Adão de comer ou não o fruto da árvore do conhecimento que havia sido proibida por Deus. À medida que não havia os conceitos de bem e mal preteritamente à Adão comer o fruto, ele não sabia que comer o fruto era mal. Visto que o que Adão sabia apenas era que Deus lhe disse para não comer o fruto da árvore. A angústia vem do fato de que a proibição de Deus implica na liberdade de Adão, pois ele pode obedecer ou não a regra Divina. Somente após o primeiro homem comer o fruto da árvore é que o pecado nasceu. Sendo assim, a angústia precede o pecado. O filósofo dinamarquês afirma que a ansiedade é o pressuposto para o pecado hereditário 
(KIERKEGAARD, 2015), sendo que Santo Agostinho foi o primeiro a nomear como peccatum originale (AGOSTINHO, 1989).

A partir do informado acima, Kierkegaard afirma que a angústia é uma forma da humanidade ser salva. É ela que informa acerca da predileção das escolhas do ser humano, da responsabilidade pessoal e a sua autoconsciência, levando o sujeito de um estado imediato inconsciente para uma reflexão consciente, que Sartre (2013) posteriormente chamará de consciência pré-reflexiva e consciência reflexiva. $O$ sujeito tornar-se-á realmente consciente de seu potencial através do aprendizado obtida da angústia. Consequentemente, a angústia pode ser uma possibilidade para o sujeito pecar, porém, ela também pode tornar-se um reconhecimento ou entendimento da verdadeira identidade e liberdade do sujeito. Nesse sentido, o pecado ocorre na própria resolução da angústia por meio do certo e do errado

\subsubsection{A angústia humana}

Os seres humanos passam por diversas situações que geram angústia no decorrer da vida. Um desses fatores é a preocupação excessiva de com quem devem se casar e de que modo deveram arbitrar para escolher a pessoa certa. Para argumentar sobre a angústia da escolha do parceiro Kierkegaard traz o exemplo de Isaque, que não teve liberdade para escolher a sua esposa. Porém, o homem, com um certo grau de segurança esperou que Deus escolhesse uma esposa jovem, bonita e que fosse amada e amável com o povo. Porém, nos falta o erótico, ainda que ele amasse o escolhido de Deus com toda a paixão que somente a juventude possa trazer, a liberdade o faltava.

Isaque nutria expectativas, porém, a facilidade estava presente não somente porque Deus escolheu por ele. Isso ocorria porque a angústia e a liberdade estavam ausentes, pois, ele não estava pessoalmente envolvido em uma decisão deveras importante, e Isaque foi fiel a uma escolha não arbitrada por ele. A partir do exemplo de Isaque, Kierkegaard indaga, como que um indivíduo continua fiel a uma escolha arbitrada por outrem? Os outros são poderes externos e o seu espírito é o poder interno. $\mathrm{O}$ autor acredita que ao mesmo tempo o espírito é um poder amigo e hostil. $\mathrm{E}$ a angústia é um medo fora de foco, disperso.

Que a angústia apareça é aquilo ao redor do que tudo gira. O homem é uma síntese do psíquico e do corpóreo. Porém, uma síntese é inconcebível quando os dois termos não se põem de acordo com um terceiro. Este terceiro é o espírito. Na inocência, o homem não é meramente um animal. De resto, se o fosse a qualquer momento de sua vida, jamais chegaria a ser homem. O espírito está, pois, presente, mas como espírito imediato, como sonhando. Enquanto se acha então presente é, de certa maneira, um poder hostil, pois perturba continuamente a relação entre alma e corpo, que decerto subsiste sem, porém, subsistir, já que só receberá subsistência graças ao espírito. De outra parte, o espírito é um poder amistoso, que quer precisamente constituir a relação. Qual é, pois, a relação do homem com este poder ambíguo, como se relaciona o espírito consigo mesmo e com sua condição? Ele se relaciona como a angústia tampouco pode apreender-se a si mesmo, enquanto ele se mantiver fora de si mesmo; nem tampouco o homem pode mergulhar no vegetativo, de jeito nenhum, pois ele está determinado, afinal, enquanto espírito; não pode fugir da angústia, pois ele ama; amá-la propriamente ele não pode, porque ele foge dela. Agora a inocência está em seu ápice. Ela é ignorância, mas não uma brutalidade animal, e sim uma ignorância que é qualificada pelo espírito, mas que justamente é angústia, porque sua ignorância se refere a nada. Aqui não há nenhum saber sobre o bem e mal etc., mas a realidade inteira do saber projeta-se na angústia como o enorme nada da ignorância. (KIERKEGAARD, 2015, p. 47) 


\subsubsection{Das construções imaginativas e o sobrenatural}

Na obra Kierkegaard traz como referência uma história em particular dos irmãos Grimm. Ele usa tal exemplo, pois, eles utilizavam contos populares para que os sujeitos tivessem lições de vida. A história escolhida foi a do jovem que saiu para aprender o que era o medo. Um dos questionamentos correntes ao longo da obra é que se a pedagogia do teatro, ou, o teatro do absurdo pode de algum modo auxiliar para que os sujeitos possam compreender de que modo podem encontrar o bem. A imaginação pode auxiliar, porém, também pode impedir que o sujeito tome decisões decisivas. Visto que, deixar de ser honesto consigo mesmo a fim de não se enganar com um poder imaginário, no qual experimenta uma possível vitória meramente imaginada em uma luta também imaginada, é desse modo que uma decisão por vir a tornar-se uma impossibilidade.

A partir da argumentação acima, surge a indagação, o que impede o sujeito tomar uma certa decisão? Segundo Kierkegaard (2015), nada impede, com exceção da própria imaginação do sujeito que está envolvido na própria tomada de decisão. Tal imaginação pode ser vinculada a culpa, pecado, medo e rejeição.

Podemos encontrar mais sobre essas construções imaginativas na obra Temor e Tremor (1979), onde Kierkegaard exemplifica através da história de Abraão, cujo personagem teria duas escolhas, seguir a Deus ou dirigir-se a Ele como monstro. Já na obra A Repetição (2009), o autor traz o exemplo do jovem que se encontra no dilema entre seguir o amor pela escrita ou se casar. Os dois casos tratam de construções imaginativas trazidas pelo autor para lidar com sentimentos como esperança e amor.

O filósofo dinamarquês acreditava que as construções imaginativas eram de suma importância e deveriam ser iluminativas. Na obra O Desespero humano (1961), Kierkegaard escreveu sobre o nada do desespero, sendo que Deus como é conhecido não é nada e a morte é um nada, e isso volta a aparecer no Conceito de Angústia. A balada dos Elfos de Von Goethe assim como A noiva de Corinto (2014) também não são nada. Somente um indivíduo único irá ter uma realidade cuja ficção jamais poderá representar. Visto isso, é necessário que as pessoas aprendam a distinção entre a realidade e as construções imaginárias. Porém, muitas coisas são difíceis de se compreende e Kierkeggard (2015) afirma que onde o entendimento desalenta é a fé que vem à tona e torna o desalento decisivo.

\subsubsection{0 primeiro pecado}

Kierkegaard na obra $O$ conceito de angústia (2015), traz a luz o exemplo de Adão e Eva que caem em pecado no paraíso. $O$ autor não se preocupa com o que fez Eva pecar e sim como ela descobriu que era uma pecadora. Ele afirma que a se pressupõe a consciência, ou seja, Eva assim como Adão tomou consciência de seu primeiro pecado por sua escolha. Ambos decidiram usar o presente de Deus, ou seja, o conhecimento da liberdade. Para Kierkegaard a doutrina da expiação só faz sentido se houver uma consciência angustiada, se removermos essa consciência dos sujeitos as igrejas poderiam ser fechadas e transformadas em salões de dança (1979).

Segundo o filósofo dinamarquês cada sujeito deve descobrir sozinho de que modo a culpa e o pecado adentraram o seu mundo. Em A repetição (1979) e Temor e Tremor (1979), ele afirma que a filosofia não deve definir a fé. Ele solicita que o seu leitor como um indivíduo único considere algumas questões, como: a culpa e o pecado podem ser transferidos de um sujeito para outro? Pode ser considerado uma epidemia como a varíola bovina? (Kierkegaard, 2015) Todos os judeus foram responsáveis para que Jesus Cristo fosse crucificado? O indivíduo único, encontra o pecado somente em si ou também no outro? Kierkegaard acreditava que o sujeito fazia uma tuto inspeção 
mais rigorosa em si mesmo e simultaneamente uma inspeção mais tolerante nos outros. No Eighteen upbuilding discourses (1992), Kierkegaard afirma que

\begin{abstract}
Não conhecemos a vida de Paulo em grandes detalhes, mas conhecemos, entretanto, Paulo, e é essa que deve ser a consideração principal. Sendo assim, do mesmo como o homem sensato se distingue por ver o cisco no olho de seu irmão, mas não ver a o grande pedaço de madeira no seu próprio, isso ocorre pois condena rigorosamente a mesma falha nos outros que ele levianamente perdoa em si mesmo. Logo a característica de uma pessoa mais profunda e preocupada é de que se julga com mais rigor, usa toda a sua engenhosidade para desculpar a outra pessoa, mas não consegue desculpar-se ou perdoarse, de fato, está convencida de que o outro é mais desculpável, porque sempre há uma possibilidade. Sendo que a única pessoa que é privada dessa possibilidade é ele mesmo. Uma confiança audaciosa é um assunto difícil, porque não é exatamente sinônimo de fraqueza mental. Pode-se muito bem parar com isso e não precisar ir mais longe, mesmo desejando julgar a Deus, isto é, se em outros aspectos confiança audaciosa é confiança audaciosa no julgamento, o que certamente requer que o julgamento de Deus penetre no pensamento e no coração, isto é, se é confiança audaciosa na misericórdia de Deus e suas palavras não são uma expressão piedosa fingida da própria falta de pensamento, que não confia em Deus, mas é consolado por ter cessado a tristeza há muito tempo. Se nenhum ser humano é capaz de se abster, ele é capaz de uma coisa - de se acusar tão terrivelmente que não consegue se abster, mas aprende a precisar de misericórdia. Com relação a isso, é difícil para uma pessoa entender a outra, porque a pessoa séria sempre coloca a ênfase em si mesma. (KIERKEGAARD, 1992, p.340)
\end{abstract}

Visto as colocações acima o autor questiona qual foi a intenção do Cristianismo, se o conceito surge por meio de definições e exemplos. Segundo Kierkegaard (2019) pecado e culpa são categorias que pertencem essencialmente à esfera religiosa. Esteticamente, a dialética da culpa segue o seguinte fluxo, incialmente o indivíduo não possui culpa, logo a culpa e a inocência aparecem como categorias alternadas na vida; em alguns momentos o sujeito é culpado de algo e em alguns momentos não o é. Se o fenômeno ocorresse ou não, o sujeito não teria se tornado culpado e em uma circunstância distinta o era considerado inócuo torna-se culpado.

A angústia é a possibilidade da liberdade, só esta angústia, é pela fé, absolutamente formadora, na medida em que consome todas as coisas finitas, descobre todas as suas ilusões. E nenhum Grande Inquisidor dispõe de tão horripilantes tormentos como a angústia, e nenhum espião sabe investir sobre o suspeito com tanta astúcia, justo no momento em que está mais debilitado, ou sabe preparar armadilhas em que este ficará preso, tão insidiosamente como a angústia, e nenhum juiz sagaz consegue examinar, sim, "ex-animar" (desalentar), o acusado como a angústia, que não o deixa escapar jamais, nem nas diversões, nem no barulho, nem no trabalho, nem de dia e nem de noite. (Kierkegaard, 2015, p.169)

O filósofo dinamarquês percebe que foi a própria proibição de Deus, para que Adão não comesse da árvore do conhecimento que levou a origem do pecado nele. Foi a proibição que surge de maneira inesperada no salto qualitativo de Adão. Kierkegaard (2015) questiona a doutrina do que ele chama de pecado ancestral. A doutrina de que Cristo e Adão se correlacionam torna tudo mais confuso. Só que somente Cristo é um indivíduo que é mais que um indivíduo. Somente por isso que ele não vem no início de tudo e sim na plenitude dos tempos. Visto isso, o pecado tem uma coerência em si mesmo.

Para Kierkegaard, todos nós somos predispostos a certas ações, algumas boas e outras más. Tanto Kierkegaard como Rosenkranz concordavam que as pessoas deveriam descobrir suas próprias disposições para que pudesse viver uma vida feliz. O sujeito deve adquirir a habilidade de sem controlar pois se não o consegue dificilmente encontrar em outrem a habilidade de fazê-lo. 
Kierkegaard afirma que especialmente entre mulheres, há casos cujo indivíduo, que está ansioso, concebe que a maioria das funções corporais triviais são algo pecaminoso. Uma pessoa pode sorrir com isso, porém, ninguém sabe se o sorriso trará a salvação ou a destruição, pois o sorriso contribui para o fechamento da individualidade trará danos irreparáveis.

\subsubsection{Mediação em Kierkegaard}

O filósofo dinamarquês julgava que cada geração possui uma tarefa própria e não precisa se preocupar de forma indevida sobre as gerações futuras e pretéritas. $O$ autor argumenta que cada geração e cada indivíduo começa a vida no seu princípio, onde, nenhuma geração é capaz de começar de outro ponto além do início dela mesma, ou seja, as gerações não começam de nenhum ponto além do início delas mesmas não levando em conta a geração anterior.

Kierkegaard era contra a ideia hegeliana de mediação na que adiciona um terceiro termo que vem entre o sujeito único e o objeto de desejo. Kierkegaard nessa argumentação se questiona se o ensino para crianças começa através da proibição ou do amor. Em outros termos, o Cristianismo diz para ensinar primeiro o que chama de "obras da carne (o negativo) ou sobre o Fruto do espírito Santo (o positivo)? Onde está a resposta, no mundo temporal ou no mundo do espírito? Devemos sempre voltar e rever os atos negativos ou avançar concentrando-nos nos atos positivos. Ou deve-se buscar o equilíbrio entre ambos? E essas questões são apenas colocadas como relevantes para grande parte da discussão.

O sujeito, para Kierkegaard, não se relaciona com o ideal por meio da geração ou do Estado, do século, essas coisas impedem que ele se relacione com o ideal, a relação se dá e deve se dar com ele mesmo, mesmo que isso o leve a errar. Devido a confusão da ideia de Estado, de comunidade, de sociabilidade e sociedade, Deus não pode mais se apoderar de um sujeito único. A imoralidade à época poderia tornar-se facilmente uma debilidade ético memorável, a transformação de um desespero sensual e suave, no qual os sujeitos tateiam como em um sonho por um conceito de Deus sem sentir o temor me fazê-lo. Pecar abertamente, zombar de Deus, sendo preferível à importância debilitante de se demonstrar a existência de Deus. Demonstrando a existência de Deus por adoração e não por demonstrações.

Kierkegaard se pergunta se uma geração pode aprender sobre a beleza, o amor, a paz, a esperança, a paciência, a ansiedade, de através da experiência da geração anterior ou se cada "sujeito" em cada geração que surge deve aprender sobre o referido acima, em grande parte por conta própria. E essa pergunta cai também sobre de que forma os sujeitos tornam-se cristãos. Os sujeitos tomam a resolução decisiva de serem cristãos ou são devido ao histórico familiar? Quais as bençãos que os cristãos ganham? A esperança é um bem em si mesmo e o desespero um mal, onde o sujeito se esforça para transformar no bem denominada esperança? A paciência é um bem e a impaciência um mal que podem ser modificados se o sujeito quiser mudar? A alma é oferecida de modo gratuito a todas as pessoas mesmo sem mérito? O futuro é uma questão de escolha ou destino, ou ambos? Para tanto, Kierkegaard responde do seguinte modo:

E esse é o prodígio da vida, que qualquer ser humano que presta atenção a si mesmo sabe que o que nenhuma ciência sabe, dado que ele sabe quem ele mesmo é, isso é o que há de mais profundo na sentença grega conhece-te a ti mesmo, que há já bastante tempo tem sido compreendida à maneira alemã, relacionada é autoconsciência pura, a quimera do idealismo. Já está mais do que na hora de se tentar entendê-la em grego e, por sua vez, compreender como teriam compreendido os gregos, caso tivessem pressupostos cristãos. (KIERKEGAARD, p.87, 2015)

A alma, é assim, a autocontradição do temporal e do eterno e, portanto, aqui pode possuirse e adquirir-se a mesma coisa ao mesmo tempo. Mas ainda: se a alma é esta contradição, 
ela só pode ser possuída no modo de ser adquirida e adquirida no modo de ser possuída. (KIERKEGAARD, p. 16, 2007)

Desse modo o homem pode ser concebido como uma síntese da psique e do corpo, e, uma síntese do temporal e do eterno. No primeiro os dois fatores são o corpo e a psique e o terceiro é o espírito, só que somente é possível falar em síntese quando o espírito é posto. A última síntese tem apenas dois fatores, o temporal e o eterno, onde estás o terceiro fator? Se o terceiro fator está ausente, não há síntese, pois, uma síntese que é uma contradição não pode se complementar como síntese se um terceiro fator está ausente, pois, o fato de a síntese ser uma contradição afirma que não é, ficando a indagação do que seja o temporal.

A angústia e o nada sempre se correspondem. No momento em que a realidade da liberdade e do espírito é postulada, a angústia é derrogada. Contudo o que então significa o nada da angústia particularmente no paganismo, significa o destino da relação entre o espírito e o externo. É a relação entre o espírito e outra coisa que não é o espírito, no qual, o destino mantém uma relação espiritual. $\mathrm{O}$ destino também pode significar o oposto, pois, é a unidade do necessário e do acidental. Tal necessidade não tem consciência de si mesma é o ipso facto., o acidental em relação ao próximo momento. Sendo assim, o destino é o nada da ansiedade.

\subsubsection{0 valor da eternidade}

A eternidade em Kierkegaard é de suma importância para compreender o desenvolvimento de sua argumentação. $O$ valor dado para a noção de eternidade transcorre em diversos de seus escritos, como nos Fragmentos filosóficos (1956), onde ele afirma que para os gregos, o eterno fica para trás assim como o passado sendo possível somente inserir ao contrário, a categoria que ele mantem deve ficar presente, sendo a repetição na qual a eternidade é inserida para frente. Nos Discursos edificantes (1943), ele afirma que uma providência zela por cada homem, fornecendolhe dois guias um que o chama para frente e outro que o chama de volta. Tais guias, não estão em oposição, tão pouco deixam o homem confuso. Ao contrário disso, ambos se encontram em eterno entendimento um com o outro, pois, um acena para o Bem, enquanto o outro chama o homem para trás do mal. Esses guias são denominados como arrependimento e remorso. $O$ homem angustiado avança de forma rápida para o novo, para o romance, para longe da experiência. Mas o que tem remorso, vem para trás exaustivamente acumula experiência. Essa ideia também está presente em seus Diários (2013), onde ele afirma que é bem verdade o que a filosofia afirma, a vida deve ser compreendida ao contrário. Porém é possível se esquecer de outro princípio, que a vida deve ser vivida para a frente. Quanto mais se reflete a cerca desse princípio, o pensamento conclusivo parece sempre ser o mesmo, de que a vida temporal nunca pode ser compreendida porque eu não posso, em nenhum momento encontrar um descanso completo por adotar uma posição para trás.

Kierkegaard se questiona sobre a força do tempo, sua capacidade de separação eterna. $\mathrm{O}$ tempo poderia ter a capacidade de apenas trazer a infelicidade, mas no instante que o sujeito troca o tempo pela eternidade, existe uma continuidade infinita onde não há de se lidar com separações eternas. Visto isso, o último suspiro deve ser para Deus, devido a salvação da sua alma.

\section{Lutero e Kierkegaard: a noção de consciência}

Nos capítulos anteriores foram tratados os principais aspectos da teologia de Lutero e do existencialismo de Kierkegaard. Nesse capítulo iremos abordar em que aspectos a consciência em Lutero e em Kierkegaard interagem. Ambos compreendem que o Cristianismo impacta de forma 
direta sobre a consciência do sujeito. Kierkegaard concorda especialmente com Lutero que o Cristianismo não possui a capacidade de ser compreendido de forma desagregada da experiência aterrorizada e aflita (KIERKEGAARD, 1967).

Entretanto, o reformista alemão e o filósofo dinamarquês compreendem que a experiência de uma consciência angustiada não é meramente um dado na experiência humana ordinária. Na realidade, mesmo que ambos pressuponham que todo ser humano é dotado de uma consciência, os autores afirmam que é necessário demasiado esforço para que a voz da consciência desperte, visto que a consciência pode ser ludibriada ou amortecida por fatores distintos. De suma importância dentre esses fatores é o falso ensinamento da Igreja em seus dias, sendo que ambos atribuem a Igreja a eliminação virtual da voz da consciência. Enquanto Martinho Lutero encarava a Igreja Romana como a portadora dessa função, Kierkegaard dava o devido papel à Igreja Luterana de sua época, em grande parte devido aos ensinamentos divulgados pelo próprio Lutero. Entretanto, Kierkegaard vê a si mesmo como capaz de refinar e purificar a voz da consciência em sua época, em oposição aos erros introduzidos na Igreja pelos ensinamentos de Lutero.

Visto isso, em seguida será exposto o ensino de Martinho Lutero sobre a consciência, posteriormente, será abordado de que modo Kierkegaard apresenta a sua compreensão acerca da consciência expondo os acordos e desacordos com o reformista alemão. Será trazido a luz de que modo cada um deles procura desenvolver a forma como a consciência deve ser desperta libertandoa do erro. Além disso, será examinado como cada um dos autores aborda a consciência que leva ao conhecimento do pecado, trazendo novamente a noção de angústia e o terror da consciência. Posteriormente será examinado como Lutero e Kierkegaard traçam a relação entre angústia da consciência e o amor de Deus em Jesus Cristo conforme o que é proclamado no Evangelho.

\subsection{A consciência em Lutero, e as desavenças com Kierkegaard}

Nesse subcapítulo será trazido a luz a noção de consciência em Lutero e onde reside a principal divergência entre o reformista alemão e o filósofo dinamarquês. Lutero e Kierkegaard divergem em maior escala sobre a compreensão da noção de amor de Deus. Para o reformador alemão, é o amor de Deus que suplanta o pecado, a ira e a morte da consciência oferecendo de forma genuína o conforto e a paz dos terrores. $\mathrm{O}$ amor jamais amedronta a consciência, pois, esse é o dever da Lei que sempre se distingue do Evangelho. De forma que o Evangelho conforta a consciência, ele também faz as obras que Deus nos determina fazer, porém, sempre como critério a necessidade do perdão.

Segundo Kierkegaard, o amor de Deus é dual pois sempre conforta e aterroriza e isso ocorre devido ao fato de que mesmo o amor abnegado de Deus que tem como fim o perdão dos nossos pecados, demanda que os sujeitos sacrifiquem a sua vida inteiramente à Deus em Cristo, como um protótipo de Cristo. $O$ pecado humano é revelado por meio do amor abnegado de Deus em Cristo revelando assim o profundo egoísmo da humanidade. A angústia gerada cria a necessidade do perdão de Cristo que é o salvador. Contudo, o ser humano é perdoado para que por meio da gratidão se esforce para moldar a sua vida cada à Cristo, sendo Ele o protótipo do amor abnegado. Para Kierkegaard, a função primária da consciência é reforçar a exigência do sacrifício da vida em prol de Deus.

Lutero infere que a consciência está relacionada diretamente as obras que o sujeito realiza e somente nessa premissa ao relacionamento com Deus. E tal noção fica clara a partir do conceito de consciência cunhado pelo reformador, onde para Lutero (2001), a consciência não é o poder de agir, todavia, o poder de julgar o que julga as obras, o propósito não é fazer, e sim falar sobre o que foi realizado e o que deveria ser realizado. A partir disso os julgamentos nos fazem ser salvos 
ou acusados diante de Deus. Para julgar corretamente as obras que foram e devem ser realizadas, sendo que a consciência recebe vários preceitos da lei natural, como a proibição do homicídio, da mentira, do adultério, honra aos pais e autoridades. São as nossas obras que tornam a nossa consciência absolvida ou acusada defronte à Deus.

A consciência sabe que Deus é o criador do ser humano e que é onipotente e verdadeiro, por isso, deve ser adorado. Todavia, a consciência não sabe quem é Deus e desse modo não sabe como adorá-lo, logo, para compensar tal ignorância, a consciência retrata para si mesma tendo como suporte a lei que foi dada concluindo convictamente que Deus é um juiz justo que outorga a lei, e consequentemente quer ser adorado mediante a obediência à lei. Deus absolve aqueles que fazem boas obras e acusa os que infringem a lei. Visto isso, todos que se se sentem acusados pela sua consciência devem fazer boas obras até que a consciência novamente os absolva diante de Deus. Lutero (1963), afirma que mesmo que o pecado traga o sofrimento pungente da consciência, os sujeitos supõem que possuem tão pouca força que algum trabalho ou mérito possa removê-lo. Esta forma de adoração é incontestável para todos os seres humanos, com exceção da fé em Cristo.

A compreensão de Deus descrita acima é imprescindível para todas as formas humanas de idolatria, contudo, segundo Lutero, a Igreja Romana torna as coisas piores ao ensinar que Deus deve ser adorado por obras criadas pela imaginação humana, como os votos monásticos ou o sacrifício da missa. Tal ensinamento traz o efeito de eclipsar a lei natural e afundar a consciência no erro. Segundo Lutero (1973), é do caráter de todos os hipócritas e falsos profetas produzir uma consciência onde não há e extinguir a consciência onde ela deve existir. A adoração auto inventada de consciência pactua com o falso ensino da Igreja Romana com a finalidade de criar uma consciência que julgue suas obras e seu relacionamento com Deus em concordância com uma compreensão errada das obras e uma ideia idólatra de Deus.

Para que a consciência seja desperta para o verdadeiro conhecimento do pecado do sujeito, é necessário que a Palavra da Lei seja pregada e revelada à consciência. Lutero acreditava que a tarefa propícia da Lei é revelar o pecado. Particularmente a Lei tem a função de revelar que o maior pecado é constituído por aquilo que a consciência em seu erro de autoilusão considerou sendo o modo de maior adoração a Deus, isto é, colocar em prática as obras da Lei torna o ser humano absolvido e salvo diante de Deus. Segundo Tappert (1959), esta é a maior idolatria praticada até o momento, e ainda predomina no mundo, falando meramente a respeito da consciência que busca ajuda, salvação e conforto em suas próprias obras, e pressupõe que Deus deve ser arrancado do céu.

À medida que a Lei revela de que modo Deus deseja ser verdadeiramente adorado, devido ao temor e a confiança em Deus e devido ao amor pelo próximo, a consciência se desespera devido as próprias habilidades do sujeito. Isso ocorre porque não encontra nele mesmo nenhuma dessas coisas nas obras realizadas, sendo assim, tudo que a consciência é capaz de encontrar é o pecado, revelado mediante a Lei de Deus, ela sentencia a culpa sobre o indivíduo, dispondo-o sob a ira eterna de Deus. Segundo Lutero (1979), do mesmo modo que a Lei revela o pecado, atinge a ira de Deus no sujeito, pois ele observa que não cumpriu os Mandamento e devido a isso Deus está ofendido e irado. $O$ intento da revelação da Lei é levar o sujeito ao desespero sobre o que ele mesmo o é, e de suas obras, porém, não leva ao desespero de Deus. Portanto, o propósito adequado da Lei é preparar o sujeito para o Evangelho conduzindo-o a Cristo. Segundo Lutero (1979), a lei apenas demonstra o pecado, aterrorizando e humilhando, desse modo, ela prepara os sujeitos para a justificação que os levam a Cristo.

Quando a consciência se torna devidamente aterrorizada através do conhecimento do seu pecado mediante a revelação da Lei, ela necessita ouvir a Palavra do Evangelho que revela que Deus tem misericórdia de todos aqueles que sentem seus pecados e se desesperam devido as suas próprias obras. Particularmente, o Evangelho revela que Deus extirpou os pecados que 
aterrorizam a consciência e os colocou sobre Cristo, e de forma conjunta, todas as consequências do pecado, como a maldição e a ira de Deus, o inferno, o diabo, a culpa e a morte. No lugar das punições, Deus dá ao sujeito tudo que a consciência dele roga que a falta, como justiça, inocência, vida, a benção e a misericórdia de Deus e o poder sobre o Diabo. Segundo Lutero (1979), devido a esta feliz troca conosco, Ele colocou sobre Si nossa pessoa pecaminosa e nos presenteou Sua pessoa inocente e vitoriosa. Vestidos sob esse a humanidade está livre da maldição da Lei, pois, o próprio Cristo, voluntariamente se tornou uma maldição por todos. Visto isso o Evangelho consequentemente, traz o grande conforto, paz e segurança de consciência em meio aos seus terrores, pois, a fé acredita que todos os males que afligem a consciência agora pertencem a Cristo, à medida que tudo que Cristo o possui, doou ao indivíduo de forma gratuita.

$O$ sujeito sente o pecado na sua consciência, e esse pecado deve ser transferido para Cristo, pois, o Evangelho diz que propriamente o pecado pertence a ele. Segundo Lutero (1979), o sujeito deve aprender em cada tentação transferir o pecado, a morte, a maldição e todos os males que nos oprimem para Cristo, do outro lado, transferir dEle a justiça, a vida e as bençãos.

A despeito da criação da lei que gera angústia e o terror da consciência, o Evangelho de Cristo avoca uma indescritível alegria e liberdade para consciência. De forma mais pontual, é a fé em Cristo que traz a liberdade do pecado, maldição, ira e morte na consciência e por conseguinte a condenação da lei. $O$ cristão é libertado pela fé da Lei, na direção da busca pela absolvição por meio das obras da Lei, assim como, da maldição da Lei que é revelada contra o pecado. Segundo Lutero (1979), esta é a liberdade que Cristo nos libertou, não de alguma escravidão humana ou autoridade tirânica, mas da ira de Deus na consciência humana. Através da Lei e da fé em Cristo, a consciência está integralmente livre da confiança nas obras.

Segundo Lutero (2001), a liberdade cristã é uma liberdade de consciência, que a liberta das obras, não que nenhuma obra seja feita, mas, nenhuma fé é colocada nela. A partir disso, surge a liberdade da consciência da compulsão da lei. A fé não livra o sujeito das obras, e sim, da ansiedade e do medo que governava as obras através da Lei. Segundo Lutero (1979), o homem justo vive como se não precisasse da Lei para censurá-lo ou constrangê-lo, com a ausência de restrição legal, fazendo mais do que a Lei exige. Por fim, é a fé em Cristo que traz a liberdade de consciência de todas as leis que foram cunhadas e concebidas por seres humanos, incluindo celibato clerical e votos monásticos. Segundo Lutero (2001), tudo aquilo que não for especificamente ordenado por Deus é indeferido tornando-se uma questão de livre escolha. A lei que rege de forma uníssona a liberdade é o amor, pois, a liberdade deve ser utilizada para edificar os fracos na fé e não os ofender.

O reformador alemão, jamais pretendeu que sua descrição da liberdade da consciência da lei, da compulsão e das tradições humanas se valesse de que os cristãos estão livres dos mandamentos de Deus. Lutero (2001) pensava que, as pessoas estariam livres de todas as coisas citadas anteriormente para que pudessem ser livres para os mandamentos, sendo o ser humano livre e remitidos das obras, esforções, leis e tradições dos homens, ligando a consciência da humanidade somente à Palavra de Deus. Particularmente, a palavra liberta o sujeito das formas que foram inventadas e atribuídas como santidade, virgindade e monaquismo, a fim de que que o sujeito possa servir a Deus conforme Ele ordenou.

Deus abençoa todos esses chamados mesmo que aparentemente pareçam comuns se comparados ao monaquismo. Desse modo, o sujeito de forma acertiva está obedecendo a Deus, a menos que seja dito para ser feito algo que contraria a Palavra Dele, sendo assim é preciso obedecer a Deus e não as pessoas. Pois se irmos por esse caminho, há a presunção de que quando os sujeitos ouvem suas mães, pais, mestres, governantes, pregadores, professores estão ouvindo a Palavra de Deus. Segundo Lutero (2014), Deus fala conosco e nos trata por meio dos ministros da Palavra para que não sejamos carregados por nenhuma onda doutrinária. 
Se o sujeito viver o seu chamado com integridade e amor, adquirirá o testemunho de uma boa consciência confirmando a autenticidade da sua fé e consequentemente testemunhará pelo sujeito no Dia do Juízo. Segundo Lutero (1979), é necessário esse testemunho de nossa consciência de que executamos bem nosso ministério e vivemos uma vida boa. Contudo, devido a persistência do pecado sobre o mais santo dos cristãos, o testemunho da boa consciência não pode resistir a aflição provocada pela Anfechtung (disputa), quando a consciência sente novamente o seu pecado e conclui que está sob a ira de Deus. Nesses momentos, o sujeito deve se desapegar das obras e se apegar a Cristo, buscando Nele a boa consciência que são incapazes de sentir em si mesmos.

\subsection{Convergências e divergências entre Kierkegaard e Lutero}

Nesse subcapítulo será tratado em que circunstâncias há um acordo entre ambos os autores e em que pontos Kierkegaard diverge de Lutero. Kierkegaard recorreu a Lutero para entender sobre a natureza e a força da consciência no evento em que o reformista alemão foi para Worms sozinho com a finalidade de confrontar o imperador e o papa. Nessa manifestação o reformista alemão expôs o poder da consciência sobre e contra todo e qualquer grupo. Kierkegaard (1978), apela para o Lutero, que está sozinho com Deus e sua consciência se opondo a oposição de todo o mundo a fim de se empenhar para despertar a consciência após ela ter sido silenciada e até eliminada quando ouvimos a Palavra de Deus por meio de outras pessoas.

Assim como Lutero, Kierkegaard pressupõe que a consciência é inerente ao ser humano, ou seja, todos já a possuem em potência, pois, se não existisse nunca poderia ser despertada. Em contrapartida é necessário um treinamento abundante para despertar a voz da consciência separando-a de todas as outras vozes que possam vir a confundi-la. Segundo Kierkegaard (1978) é pressuposto e reconhecido que todo o ser humano possui uma consciência, e há um rigor necessário para tê-la, que está vinculado a uma aprendizagem rigorosa e extensa. Sendo assim a eternidade coloca a consciência dentro de cada indivíduo, desse modo criando a exigência de cada um formar uma consciência por si mesmo. Segundo Kierkegaard (1978) se é compelido a dizer que quando todos forem julgados na eternidade será exigido inicialmente que todo o ser humano se supriu de uma consciência.

A aprendizagem extensa e rigorosa mencionada por Kierkegaard exigida para atingir a consciência é bem diferente da noção de Lutero. Contra o apelo de Lutero à revelação e a pregação da Lei para despertar a consciência, Kierkegaard nos envia diretamente à solidão para descobrir e desenvolver a voz da consciência. Segundo Kierkegaard (2010), se o ouvinte teme a quietude, mesmo que esteja fazendo o seu melhor para ter uma consciência (sem a quietude a consciência não existe de todo) e ter uma boa consciência, deve continuar. Quietude não é a quietude da morte na qual o sujeito perece, não é a doença para morte, é a transição para a vida. $O$ silêncio e a solidão são necessários pois porque a voz da consciência é abafada pelas vozes de outros seres humanos, de modo que ou acaba se tornando uma voz entre muitas ou simplesmente é completamente silenciada. Segundo Kierkegaard (2009, XV), na temporalidade a consciência já quer fazer de cada um separadamente um único indivíduo, mas também na temporalidade, que contém a inquietação o ruído, o esmagamento a multidão, a própria consciência é ensurdecida. $O$ conhecimento está em ouvir no silencia e na solidão da voz da consciência, de modo que a voz da consciência é a única que será ouvida.

No momento em que a voz da consciência é ouvida no silencio da solidão e na quietude, o sujeito é convocado pela consciência tornando-se um só. Para Kierkegaard, é isso que irá formar a base da igualdade humana, pois todos podem se tornar indivíduos singulares, em silêncio ouvindo a voz da consciência. $O$ indivíduo se torna único quando a consciência o tira da relação com os outros e o coloca unicamente em relação com Deus, a fim de que esteja unicamente com 
Ele na relação de consciência. Em Works of Love (KIERKEGAARD, 2013), o autor afirma que relacionar-se com Deus é precisamente ter consciência, assim, uma pessoa não poderia ter nada na sua consciência se Deus não existisse, porque a relação com Deus é a consciência.

Assim como a relação do indivíduo com Deus, a consciência retrata o nosso conhecimento do conhecimento de Deus acerca de nós. Ser conhecido por Deus constitui a possibilidade de o sujeito alcançar o que Kierkegaard chama de personalidade. Segundo Kierkegaard (1978) é a consciência que forma uma personalidade, a personalidade é determinada individualmente confirmada por ser conhecida por Deus na possibilidade da consciência, mesmo que a consciência durma a possibilidade disso é constitutiva.

Se o sujeito se tornar uma personalidade por ser conhecido por Deus, logo quanto mais transparente o sujeito é para Deus, mais ele é uma pessoa. Há, portanto, uma finalidade na consciência, ou seja, tornar o sujeito uma pessoa cada vez mais transparente perante Deus. Na Fear and trembling and the sickness unto death (KIERKEGAARD, 2013), antes de Deus eles eram indivíduos solitários, os indivíduos que se senta em uma vitrine não fica tão envergonhado quanto todo ser humano se mostra inteiramente diante de Deus, sendo essa a relação de consciência. Além do mais, se Deus vê o indivíduo em consciência, logo, o indivíduo deve olhar para Deus em consciência. Para Kierkegaard (Works of love, 2013) é na consciência que Deus olha para uma pessoa, agora, de forma integral deve olhar para ela, e desse modo Deus faz o ser humano subir. É desse modo que Kierkegaard experimentou seu conhecimento diante de Deus. Segundo Kierkegaard (1979), Deus vê a minha consciência e agora tornou-se impossível desmemoriar que ele me vê, sendo visto por Deus, tive que olhar para Deus.

A relação da consciência do sujeito com o próprio Deus não é meramente uma descoberta na solidão e no silêncio, mas é desenvolvida e expressa somente na solidão e no silêncio. Quando o sujeito se vê em consciência, Deus quer que o sujeito olhe somente para Ele em todas as coisas em consciência, sem consultar os outros sobre o relacionamento com Ele, pois, na verdade alguém é subjetivamente uma pessoa na medida em que consulta apenas com Deus e sua consciência é capaz de suportá-la. Desse modo, a consciência leva o sujeito a dar ouvidos as Palavras de Jesus Cristo no Sermão da Montanha, no qual o sujeito deve fechar a porta e orar em segredo ao nosso Pai. Segundo Kierkegaard (1979) a primeira coisa que o homem religioso faz é trancar a porta e falar em segredo.

Orar a Deus em segredo, aconselhar-se somente com Deus em silêncio e solidão, não falar a outros sobre a relação pessoal com Deus é o único modo de expressar a relação entre Deus e a consciência. Tal prática religiosa está longe de ser opcional e piedosa, trancar a porta e orar a Deus é o que há de mais elevado na vida humana. Para Kierkegaard (1979) o cristianismo ensina imediatamente a pessoa o caminho mais curto para encontrar o mais elevado, feche a porta e ore por Deus pois Deus é certamente o mais elevado.

O cristianismo também diz que o sujeito deve levar as Escrituras para o quarto, a fim de que, diante de Deus o sujeito se torna obrigado a seguir as Escrituras em consciência. Dado que está sendo trazido o Novo Testamento para o relacionamento do sujeito com Deus em consciência, o sujeito não deve consultar os outros a respeito do significado do que é lido, consultando somente a Deus, para que a sós diante de Deus assumam total responsabilidade pela interpretação e relacionando-se a interpretação diretamente a Deus, pedindo a Ele o significado do que o sujeito lê.

Assim como Lutero, Kierkegaard concebe que o coração da vida cristã como sendo falar a Deus em oração, e Deus fala com o sujeito mediante a Palavra, porém, diferentemente de Lutero, que argumenta que isso ocorre por meio da pregação e dos sacramentos, Kierkegaard acredita que isso deve acontecer quando o sujeito se isola em seu quarto de porta trancada. A consciência leva o sujeito a buscar e fomentar o seu relacionamento com Deus somente no meio privado, e não na 
assembleia pública da comunidade. Quanto mais o sujeito fala com os outros em público, mais acaba abolindo o relacionamento com Deus na consciência.

O propósito de se estar sozinho diante de Deus conjuntamente com as Escrituras é ser ensinado de forma direta por Deus evitando ruídos humanos. Quando o ser humano é ensinado por Deus, Ele revela o amor pelo sujeito, não somente que Deus ama a humanidade, mas o de suma importância é que Deus é amor. Todavia é justamente essa revelação que deve ser guardada com mais cuidado, impedindo que outro ser humano ensine o próprio sujeito sobre Deus, porque o amor que é Deus está em contradição direta com todo e qualquer entendimento humano do amor.

O ser humano compreende que o amor é a maior clemência, porém Deus também acaba por revelar que o amor é simultaneamente o requisito mais árduo. É crível compreender que o amor derrama sobre o ser humanos o maior conforto, porém Deus acaba por revelar que simultaneamente é o mais assustador. É possível compreender que o amor é a eliminação da solidão, porém, ser amado por Deus isola o sujeito do mundo inteiro e a cada momento fica mais difícil ser compreendido pelos outros. Os sujeitos julgam que o dom do amor elimina requisitos, porém Deus demonstra que quanto mais Deus ama os sujeitos, mais surge os sentimentos de obrigação de rendimento a Deus, levando ao sacrifício completo para Ele. Erroneamente se pensa que o amor perdoa o pecado, mas o que ocorre é que somente o amor de Deus pode revelar o pecado.

\section{Conclusão}

Relacionando as argumentações de Kierkegaard e Lutero, é possível vislumbrar que o amor segundo o filósofo dinamarquês é o absoluto terror assim como o maior conforto, visto isso, Lutero, deve estar errado sobre a relação entre Lei e Evangelho. O que centraliza a noção de Lutero sobre a consciência é o papel da Lei em revelar o pecado para a sujeito por meio da ira de Deus. Enquanto o Evangelho remove o pecado da consciência por amor. Por sua vez, o filósofo dinamarquês, concebe que a divisão entre Lei e Evangelho acarreta a eliminação da consciência e do Cristianismo.

Segundo Kierkegaard (1979), Lutero separa a Lei do Evangelho, tornando o cristianismo um otimismo, antecipando que haverá uma vida fácil nesse mundo. Tal conclusão vem à medida que, a cristandade à época de Kierkegaard, doutrinou que os seres humanos foram perdoados pelo amor de Deus para que os sujeitos pudessem desfrutar a vida neste mundo. Só que Kierkegaard (1979), alerta que na cristandade foi realizada uma tentativa de eliminar a consciência introduzindo a expiação dos pecados por meio da fé no ato salvístico de Deus para que o sujeito possa deleitar a vida. Tal fenômeno é a maior recaída possível para a humanidade.

Visto isso, Kierkegaard argumenta que a descoberta decisiva de Lutero de que o Evangelho é o único capaz de trazer a paz e o conforto para as consciências aterrorizadas, acaba levando a Igreja para um caminho cuja consequência é a eliminação total da consciência. Segundo Kierkegaard (1979), Lutero "vira" o cristianismo de "cabeça para baixo", pois para ele o Cristianismo existe para acalmar e tranquilizar as consciências angustiadas. Para o filósofo dinamarquês, Cristo veio além dos intuitos descritos acima. O Salvador, segundo ele, também é responsável pelas angústias geradas nas consciências humanas devido ao seu amor incondicional.

Enquanto Deus revela o amor dele à consciência do sujeito, Ele simultaneamente revela o pecado do sujeito. $\mathrm{O}$ amor de Deus mostra que o que é chamado de amor na verdade é uma aliança de amor-próprio. $\mathrm{O}$ amor de Deus é um amor altruísta, ou seja, que não busca benefício próprio, porém, convoca a todos a sacrificar tudo em abnegação a fim de dar espaço para Deus, visto que a aliança amor-próprio só elimina a relação com Deus. 
Por amor, porém, Deus entende o amor abnegado no sentido divino, o amor abnegado que tudo sacrifica para dar lugar a Deus, mesmo que o sacrifício pesado se tornasse ainda mais pesado porque ninguém o entendia, algo que em outro sentido pertence ao verdadeiro sacrifício, na medida em que o sacrifício que as pessoas entendem tem sua recompensa, afinal, na aprovação popular e, nessa medida, não é verdadeiro sacrifício, que deve ser incondicionalmente sem recompensa. (KIERKEGAARD, Works of Love, p.119)

Quando o sujeito se envolve com Deus por meio da consciência, em retiro e no silêncio do quarto, é possível descobrir o amor genuíno de Deus, que exige incondicionalmente do sujeito sacrificar tudo por amor a ele, com o único benefício de se relacionar como próprio criador. Quando esse amor é revelado o pecado também é revelado, pois agora está claro na consciência do sujeito de que ele é culpado por crucificar o amor que é Deus em nome da compreensão humana do que é o amor. "Você recebe uma culpa, uma culpa gritante, colocada sobre sua consciência - ou seja, que você também é cúmplice de seu sofrimento e morte inocentes. (KIERKEGAARD, 1979, p.173)"

O paradoxal do sistema é que, ao mesmo tempo em que são criados horrores na consciência humana devido a revelação do amor de Deus é também ele que fornece o único acesso ao Seu amor, pois a consciência aterrorizada auxilia a busca de Cristo com fé. "Veja, isso é o Cristianismo. Se você não está consciente de ser um pecador a ponto de na ansiedade da consciência angustiada você não ousar outra coisa senão se comprometer com Cristo - então você nunca se tornará um cristão. (KIERKEGAARD, 1979, p.199)".

Segundo Kierkegaard, Lutero, está correto no sentido de que apenas a consciência aterrorizada compreende a expiação, já que somente a expiação dos pecados é suficiente para a compreensão da consciência angustiada. No entanto, Lutero está errado ao distinguir Cristo da experiência da consciência angustiada, visto que não é apenas a força que me leva a Cristo, mas também a fonte do meu compromisso singular com Cristo, de modo que estou simultaneamente disposto a arriscar tudo e sacrificar tudo pelo Salvador que morreu por meus pecados.

Esta disposição de arriscar tudo, de sacrificar tudo, em face do desprezo e da perseguição do mundo, é para o filósofo dinamarquês a liberdade de consciência.

A qualificação 'consciência' é tão interna que é necessária toda a filtragem possível para encontrá-la; mas se for encontrado, se realmente é isso e apenas aquilo que me determina - então todos os regulamentos serão pendurados - eu rio deles. É precisamente porque 'a consciência' é infinitamente sagrada para o homem que é totalmente consciencioso que ele deseja oposição, constrangimento. (KIERKEGAARD, 1978, p.71)

Sendo assim, Kierkegaard jamais defenderia a liberdade de consciência como liberdade do modo como Lutero o faz, uma vez que a nossa liberdade só é encontrada quando amamos a Cristo com uma paixão tão distinta que estamos dispostos a arriscar tudo por ele e concomitantemente sacrificar tudo por ele. Segundo Kierkegaard (1978), o sujeito que é capaz de ficar sozinho no mundo, consultando apenas a sua consciência é um herói. Kierkegaard apela para Lutero quando argumenta em favor do despertar e fortalecimento da consciência no silêncio e na solidão, trazendo a luz o evento de Worms, onde o monge solitário enfrentou o Imperador e o Papa. Lutero, com a consciência desperta, estava disposto a fazer todos os sacrifícios por Deus, enquanto o "segundo" Lutero, o que desenvolveu a teologia da igreja a época de Kierkegaard, leva a uma visão que acarretará a abolição da consciência, buscando o perdão dos pecados em Cristo para que seja possível se divertir em vida. 


\section{Referências}

AgostinHO Santo, Bispo de Hipona. As confissões. 2. ed. São Paulo: Quadrante, 1989. 219 p. AUGUSTINE, Saint. Basic Writings, ed. Whitney Oates (New York: RandomHouse, 1948), in the Confessions, Bk. XII, 1948.

BAINTON, Roland Herbert. Here I stand: A life of Martin Luther. Abingdon Press, 2013.

BENTO, SÃO. A regra de São Bento. Tradução de D. Basílio Penido. Petrópolis: Vozes, 1993.

Britannica's editors .https://www.britannica.com/event/Diet-of-Worms-Germany-1521. Acessado em 20 de novembro de 2020.

Britannica encyclopedia. https://www.britannica.com/biography/Soren-Kierkegaard. Acessado em 20 de novembro de 2020.

DE LUTERO, BÍBLIA SAGRADA COM REFLEXÕES. Nova tradução na linguagem de hoje. São Paulo: Sociedade Bíblica do Brasil, 2012.

DUNCAN, Elmer H.; WALKER, Danny Floyd. Sören Kierkegaard. Word Books, 1976.

FAHLBUSCH, Erwin et al. (Ed.). The encyclopedia of Christianity. Wm. B. Eerdmans Publishing, 1999.

GARDINER, John Eliot. Nineteenth-century philosophy. Simon and Schuster, 1968.

HEGEL, G. W. F. Prefácio à Fenomenologia do Espírito. Biblioteca Marxista na Internet. https://www.marxists.org/portugues/index.htm. Acesso em setembro de 2020

HENDRIX, Scott H. Martin Luther: visionary reformer. Yale University Press, 2015.

HENDRIX, Scott H. The Controversial Luther. Word \& World, v. 3, n. 4, p. 391-397, 1983.

HILLERBRAND, Hans; MCKIM, D. K. The Legacy of Martin Luther. The Cambridge Companion to Martin Luther, v. 234, 2003.

HOWLAND, Jacob. Kierkegaard and Socrates: A study in philosophy and faith. Cambridge University Press, 2006.

KIER KEGAARD, Soren. A repetição. Portugal: Relógio D'água, 2009. 152 p.

KIERKEGAARD, Søren Aabye. Adquirir a sua alma na paciencia: dos quatro discursos edificantes (1943). Assirio \& Alvim, 2007.

KIERKEGAARD, Søren. Concluding Unscientific Postscript to Philosophical Fragments: A Milnical-Pathetical-Dialectical Conlpilation, An Existential Contribution, vol. I. Trans. Howard V. Hong and Edna H. Hong, Princeton: Princeton University Press, 1992.

KIERKEGAARD, Søren. Concluding unscientific postscript to the philosophical crumbs. 2009.

KIERKEGAARD, Søren. Christian discourses: The crisis and a crisis in the life of an actress. Princeton University Press, 1997.

KIERKEGAARD, Søren. Diario de um sedutor; Temor e tremor; O desespero humano. São Paulo: Abril, 1979. 281 p.

KIERKEGAARD, Søren. Diario. Bur, 2013.

KIERKEGAARD, Søren Aabye. Søren Aabye Kierkegaard. Early years, v. 1813, p. 1.1, 1836.

KIERKEGAARD, Søren. Eighteen upbuilding discourses. Princeton University Press, 1992.

KIER KEGAARD, Søren. Fear and trembling and the sickness unto death. Princeton University Press, 2013.

KIERKEGAARD, Søren; CANCLINI, Arnoldo. Fragmentos filosóficos. Casa Unida de Publicaciones, 1956.

KIERKEGAARD, Søren. Kierkegaard's Writings, XV, Volume 15: Upbuilding Discourses in Various Spirits. Princeton University Press, 2009

KIERKEGAARD, Søren. Kierkegaard's Writings, XVI, Volume 16: Works of Love. Princeton University Press, 2013. 
KIERKEGAARD, Soren A. O conceito de angústia: uma simples reflexão psicológicodemonstrativa direcionada ao problema dogmático do pecado hereditário. Editora Vozes Limitada, 2015.

KIERKEGAARD, Sören. O desespero humano:(Doença até à morte). In: O desespero humano:(doença até a morte). 1947. p. 211-211.

KIERKEGAARD, Søren. Søren Kierkegaard's journals and papers/1848-1855. Indiana University Press, 1978.

LOWRIE, Walter. A short life of Kierkegaard. Princeton University Press, 2013.

LUTERO, Martinho. Preleção sobre Gênesis. Obras Selecionadas. São Leopoldo: Sinodal; Porto Alegre: Concórdia; Canoas: Ulbra, v. 12, p. 53-530, 2014.

LUTHER, Martin. Concerning the Ministry, 1523. Church and Ministry II, p. 3-44, 1958.

LUTHER, Martin; PELIKAN, Jaroslav Jan. Commentaries on 1 Corinthians 7, 1 Corinthians 15; Lectures on 1 Timothy. Concordia Publishing House, 1973.

LUTHER, Martin. Commentary on Galatians. Kregel Publications, 1979.

LUTERO, Martinho; PASCHOAL, Erlon José. Da liberdade do cristão: prefácio a Bíblia. SciELO-Editora UNESP, 1998.

LUTHER, Martin. Lectures on Genesis, Chapters 15-20. Concordia Publishing House, 1961

LUTHER, Martin. Luther's Works/26 Lectures on Galatians 1535, chapters 1-4. Luther's works, 1963.

LUTHER, Martin. The Judgment of Martin Luther on Monastic Vows from 55-Volume American Edition Luther's Works on CD-ROM. 2001.

KIERKEgAARD, Søren. Two Ages the Age of Revolution and the Present Age a Literary Review. 2000.

LUTHER, Martin. What Luther Says: An Anthology. Concordia Publishing House, 1959.

OSTENFELD, Med Ib. Soren Kierkegaard's Psychology. Wilfrid Laurier Univ. Press, 1981.

REU, Johann Michael. Luther and the Scriptures. Wartburg Press, 1944.

SARTRE, Jean-Paul. A transcendência do ego. Editora Vozes Limitada, 2013.

SCHAFF, Philip. History of the Christian Church. 8 vols. Grand Rapids: Wm. B. Eerdmans Pub. Co, v. 4, 1910.

SKINNER, Quentin. As fundações do pensamento político moderno. São Paulo: Companhia das Letras, 1996.

SWENSON, David F. Something about Kierkegaard. Mercer University Press, 2000.

TAPPERT, Theodore Gerhardt (Ed.). The book of concord: The confessions of the Evangelical Lutheran Church. Fortress Press, 1959.

VON GOETHE, Johann Wolfgang. A Noiva de Corinto. São Paulo: Editora Melhoramentos, 2014. $28 \mathrm{p}$.

Autor(a) para correspondência / Corresponding author: Heloisa Allgayer. heloisaallgayer@gmail.com 